\title{
A Case Diagnosed Late with Suspicion: A Foreign Body Aspiration
}

\section{Geciken ve Şüphe ile Çözülen Bir Tanı: Yabancı Cisim Aspirasyonu}

\author{
(D) Volkan Tosun1, (D Selen Mandel1, (D Bekir Can Gümüşlü², (D Ülkem Koçoğlu Barlas
}

${ }^{1}$ University of Health Sciences Turkey, İstanbul Bağcılar Training and Research Hospital, Clinic of Pediatrics, İstanbul, Turkey

${ }^{2}$ University of Health Sciences Turkey, İstanbul Bağcılar Training and Research Hospital, Clinic of Otorhinolaryngology, İstanbul, Turkey

\section{Abstract}

Foreign body aspiration is the cause of a frequently seen respiratory problem in the pediatric population. It may be life threatening if diagnosed late. The clinical symptoms as well as physical examination findings are similar to those of upper and lower respiratory tract infections; therefore, it is easily missed.

A 15-month-old male patient came to emergency room with respiratory problems that started acutely. Physical examination showed symptoms that were consistent with upper respiratory tract obstruction; therefore, the patient was started on inhaler treatments. The chest X-ray and the primary examination with a laryngoscope showed no specific results. The patient was then admitted to pediatric intensive care unit in order to continue his treatment. The patient showed improvement in time; however, his condition declined as the dosage of the inhaler treatment was decreased. Second examination with a laryngoscope was performed and a foreign body in the larynx was found. The foreign body was removed in the operating room and the complaints of the patient were completely gone. Foreign body aspiration is a clinically important situation for the pediatric population due to the fact that it is seen very commonly and causes acute respiratory problems. The clinical findings are similar to those of upper and lower respiratory tract obstructions or infections and it can be diagnosed easily with a careful physical examination.

Keywords: Delayed diagnosis, foreign body aspiration, laryngoscopy, pediatrics

\section{Öz}

Yabancı cisim aspirasyonu, çocukluk çağında sık görülen bir solunum sıkıntısı nedenidir. Geç tanı konulduğunda hayatı tehdit eden durumlara yol açabilir. Klinik şikayetleri ve fizik muayene bulguları üst ve alt hava yolu enfeksiyonlarına benzer klinik tablolar oluşturduğundan tanıda kolaylıkla gözden kaçabilir.

On beş aylık erkek hasta çocuk acil servisimize ani başlayan solunum sıkıntısı ile başvurdu. Fizik muayene bulguları üst solunum yolu tıkanıklığı düşündüren hastaya ilk başta nebül tedavisi uygulandı. Çekilen toraks bilgisayarlı tomografisinde ve yapılan ilk laringoskopik muayenede özellik saptanmayan hasta takip ve tedavisinin devamı için çocuk yoğun bakım ünitemize yatırılı. Illk başta tedaviye iyi yanıt veren fakat tedavinin azaltılmasıyla birlikte şikayetleri tekrar artan hastaya ikinci laringoskopik muayene yapıldı ve larinkste yabancı cisme rastlandı. Ameliyathane koşullarında çıkarılan cisim sonrası hastanın şikayetleri tamamen geriledi.

Yabancı cisim aspirasyonları çocukluk çağında sık görülmesi, ani solunum sıkıntısına yol açması, klinik bulguları ile üst ve alt solunum yolu tıkanıklı̆ı ya da enfeksiyonu yapan nedenleri taklit etmesi ve dikkatli muayene ile kolaylıkla tanısının konulması nedeniyle çocukluk çağının önem arz eden durumudur.

Anahtar kelimeler: Gecikmiş tanı, laringoskopi, pediyatri, yabancı cisim aspirasyonu

\section{Introduction}

Foreign body aspiration to the tracheal-bronchial system is a commonly seen problem with important morbidity and mortality rates $(1,2)$. It is seen mostly in male patients under three years old and causes 7\% of deaths in this age group (3). Clinical findings differ depending on the location of the foreign body as well as whether the blockage is complete or partial (4). In some cases, because it can be confused with other reasons for respiratory problems, it

Address for Correspondence: Volkan Tosun, University of Health Sciences Turkey, İstanbul Bağclar Training and Research Hospital, Clinic of Pediatrics, İstanbul, Turkey

E-mail: volkan.tosun.91@hotmail.com ORCID ID: orcid.org/0000-0002-7258-1188 Received: 11.06.2021 Accepted: 19.08.2021

Cite this article as: Tosun V, Mandel S, Gümüşlü BC, Koçoğlu Barlas Ü. A Case Diagnosed Late with Suspicion: A Foreign Body Aspiration. Bagcilar Med Bull 2021;6(4):451-454

${ }^{\circ}$ Copyright 2021 by the Health Sciences University Turkey, Bagcilar Training and Research Hospital Bagcilar Medical Bulletin published by Galenos Publishing House. 
may be diagnosed late. In our case study, we present a case of a male patient who came to the emergency room (ER) with acute respiratory problems, who was then followed at the pediatric intensive care unit (PICU) with physical findings of upper respiratory tract obstruction and treated accordingly. A further examination was performed with laryngoscope once the patient was non-responsive to medical treatment.

\section{Case Report}

A 15-month-old male patient came to the ER with respiratory problems, wheezing and coughing for the past three days. The patient's symptoms developed very acutely and he applied to several other centers. The provided treatments did not help the patient's symptoms; therefore, he came to our ER. Preliminary physical examination showed that overall status of the patient was average, and he was conscious. Respiratory system examination showed stridor and suprasternal retractions. Other system examinations had no particular findings. First blood gases showed pH: 7.41, $\mathrm{pCO}_{3}: 32 \mathrm{mmHg}, \mathrm{HCO}_{3}: 2.7$, lactate: 0.9 and base excess: 3.6. There was no specific finding in the chest X-ray (Figure 1). The patient was started on ampicillin sulbactam and cephotaxime as antibiotics, salbutamol, budesonide and adrenalin as inhaler treatment and methylprednisolone and magnesium sulphate as bronchodilator treatment. Computed chest tomography was performed since the respiratory problems had an acute beginning, and an increase in peribronchial intensity and atelectasis in the right lung was seen. No foreign object was seen in the laryngoscopic examination performed by the ear nose throat doctor. The symptoms of the patient continued despite the treatment and interventions in the ER and the patient was then transferred to PICU.

Physical examination of the patient in the PICU showed the overall status of the patient to be average, conscious with Glasgow Coma scale of 15 (eyes: 4, verbal: 5, motor: 6). Respiratory system examination showed stridor with suprasternal retractions. 32 breaths per minute, heart rate of 100 beats/minute and blood pressure of 120/75 (90) mmHg were also noted. Examination of other systems showed no findings. Blood gases showed pH: 7.36, $\mathrm{pCO}_{2}: 39 \mathrm{mmHg}, \mathrm{HCO}_{3}: 21.2$, lactate: 1.4 , base excess: 2.3. Complete blood count showed leukocyte number as 15,280 (normal: 4.000-12,000), biochemical parameters showed C-reactive protein as $7.9 \mathrm{mg} / \mathrm{L}$ (normal: $0-5$ ) and procalcitonin level resulted as $1.23 \mathrm{ng} / \mathrm{mL}$ (normal 0.02 0.5). The patient was started on ampicillin sulbactam 150 $\mathrm{mg} / \mathrm{kg} /$ day in 3 equal doses, dexamethasone $0.15 \mathrm{mg} / \mathrm{kg} /$ dose in 4 doses, $3 \%$ hypertonic saline inhaler $3 \mathrm{cc} /$ dose in 4 doses, ipratropium bromide inhaler $250 \mathrm{mcg} / \mathrm{dose}$ in 4 doses, salbutamol $0.15 \mathrm{mg} / \mathrm{kg} /$ dose in 8 doses and $1 / 1.000$ inhaler epinephrine $3 \mathrm{~mL} /$ dose in 4 doses. The patient's condition improved with the treatment; however, once the dosing of the medication was decreased, the patient's symptoms increased. On the sixth day of the patient's follow-up, his condition got worsened and the patient was consulted to a ear, nose and throat specialist once more. The second laryngoscopic examination showed suspicion of a foreign body, unable to be identified to the edema in the lateral side of the vocal cord, and the patient was taken to the operating room. Direct laryngoscopic examination under anesthesia showed a foreign body located in the left pyriform sinus. The foreign body was removed using forceps (Figure 2). It was pumpkin seed shell (Figure 3). Following the operation, the patient's symptoms decreased immediately and was followed at the PICU one more day. Then, he was transferred to pediatric ward.

\section{Discussion}

Foreign body aspiration is commonly seen in children under 3 years old but can be seen in all age groups and is a pediatric emergency (5). Children under 3 years old are in constant movement in order to discover their surroundings and because their fine motor skills start developing, they bring everything they find into their mouths. However, since their dental development is not complete, they mostly

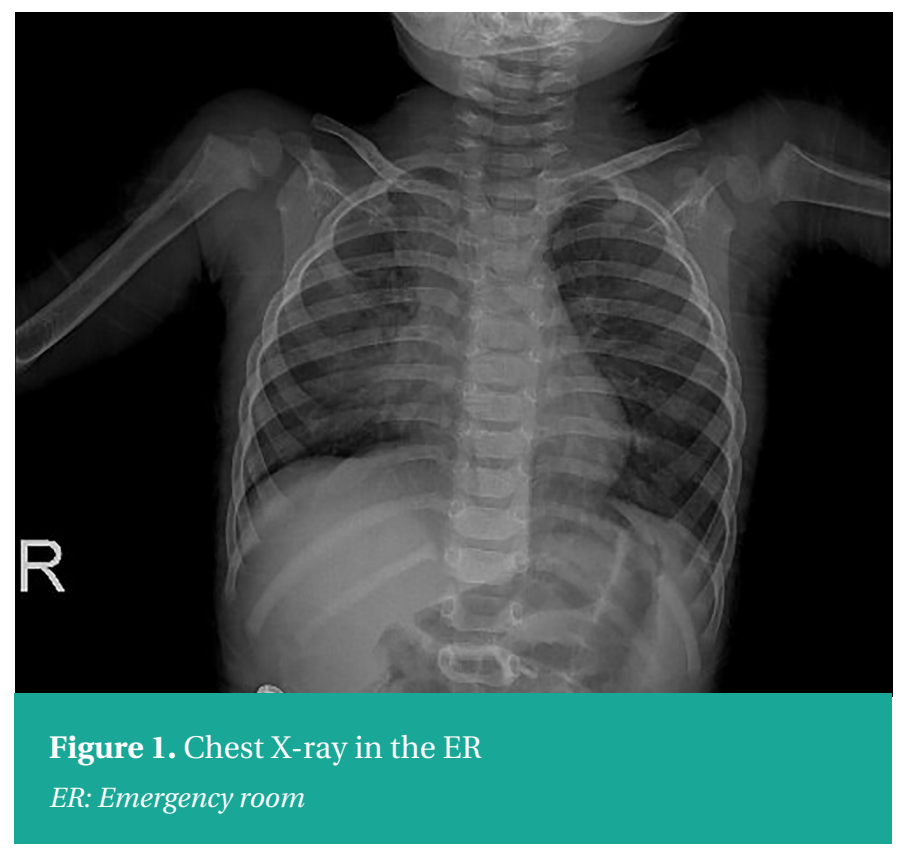


fail at chewing (6). This increases the risk of aspiration of crustacean food.

Patient history is very important in the foreign body aspiration cases. The presence of someone who has witnessed the aspiration moment and the information that they provide help the diagnosis. However, in $1 / 3^{\text {rd }}$ of the cases, no such witness is seen or the information provided is not trustworthy $(7,8)$. In this case, there are specific physical examination symptoms that the physician must be alert about. Most commonly seen examination findings are the decrease of respiratory sounds on one side, wheezing,

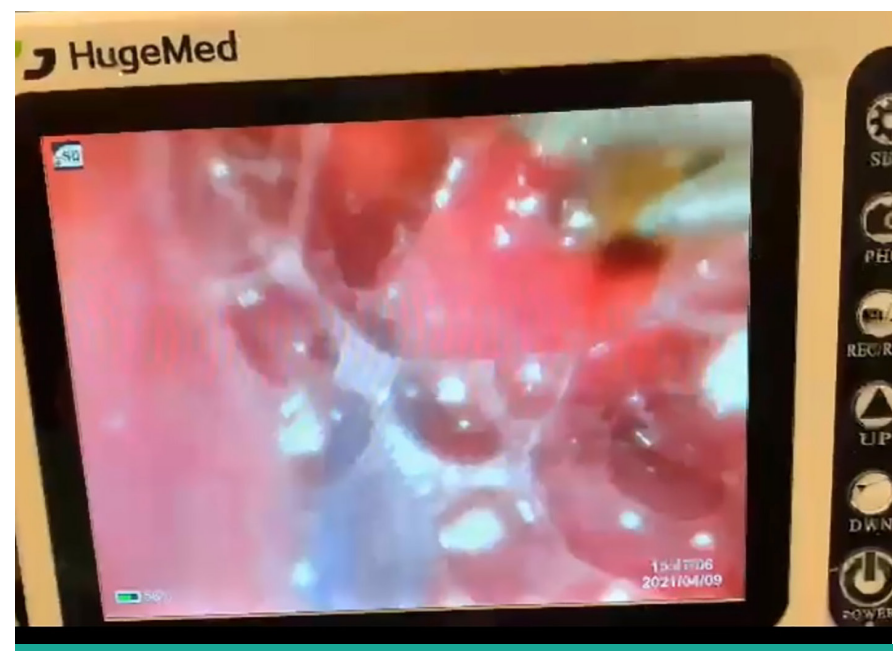

Figure 2. Foreign body seen in the rigid laryngoscopy

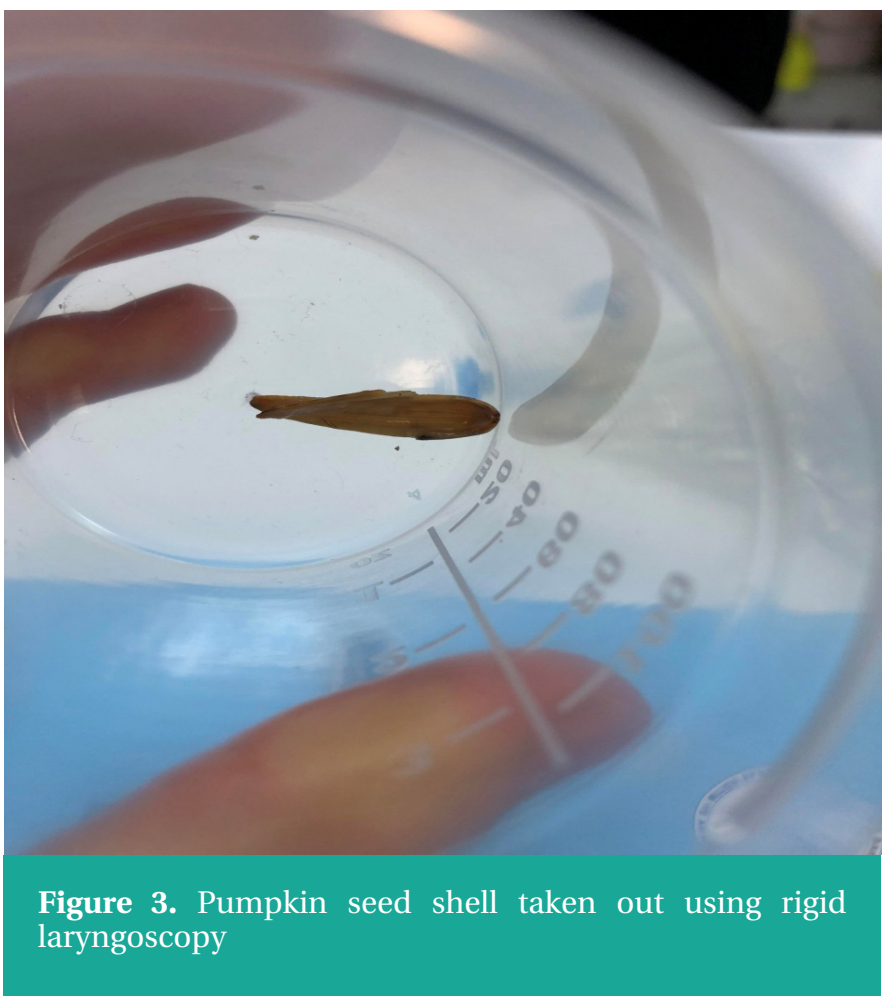

stridor and respiratory difficulty. On the other hand, physical examination can be completely normal as well (4). In our case, the patient had a history of eating nuts few days prior to coming to the hospital and the symptoms starting acutely were the reasons why foreign body aspiration was considered and even though the first laryngoscopic examination showed no results, the second examination helped the diagnosis.

Imaging can be used in all cases suspected of foreign body aspiration. The most common imaging technique is chest $\mathrm{X}$-ray. However, in $1 / 3^{\text {rd }}$ of the cases, the X-ray can be normal, and normal imaging does not exclude foreign body aspiration (4). Computer tomography can be used in order to evaluate the infectious situations following the obstruction. In cases where the foreign body is not radiopaque, the diagnosis is very difficult. If the foreign body is stuck in the trachea, because it can cause edema, it may be difficult to see it in a laryngoscopy. In our case, the foreign body was not visible in the chest X-ray and the computer tomography because it was not radiopaque. First laryngoscopic examination showed no foreign body because of the location of the object as well as the edema it caused. In such cases, it is important to repeat the imaging techniques (9). In our case, because the symptoms did not improve with medical treatment and clinical suspicion continued, laryngoscopy was repeated and the patient was diagnosed with foreign body aspiration.

Most common treatment in foreign body aspiration is the removal of the object using rigid laryngoscope (10). In all cases suspected of foreign body aspiration, laryngoscopy should be performed (11).

Foreign body aspiration should be considered in children who have respiratory problems which start acutely, does not decrease despite the appropriate treatment and are repeating. Patient history, physical examination and radiologic findings should be considered together in order to reach the diagnosis. Identifying a foreign body aspiration early on and doing the treatment accordingly can save a child's life and increase their life quality.

\section{Ethic}

Informed Consent: For the study, written and verbal consent was obtained from the family.

Peer-review: Externally and internally peer-reviewed.

\section{Authorship Contributions}

Concept: V.T., Ü.K.B., S.M. B.C.G., Design: V.T., Ü.K.B., S.M. B.C.G., Data Collection or Processing: V.T., Ü.K.B., 
S.M., Analysis or Interpretation: V.T., Ü.K.B., S.M., Drafting Manuscript: V.T., Ü.K.B., S.M., B.C.G., Critical Revision of Manuscript: Ü.K.B., Final Approval and Accountability: V.T., S.M., B.C.G., Ü.K.B.

Conflict of Interest: No conflict of interest was declared by the authors.

Financial Disclosure: The authors declared that this study received no financial support.

\section{References}

1. Foltran F, Ballali S, Rodriguez H, Sebastian van As AB, Passali D, Gulati A, et al. Inhaled foreign bodies in children: a global perspective on their epidemiological, clinical, and preventive aspects. Pediatr Pulmonol 2013;48(4):344-351.

2. Rodríguez H, Passali GC, Gregori D, Chinski A, Tiscornia C, Botto H, et al. Management of foreign bodies in the airway and oesophagus. Int J Pediatr Otorhinolaryngol 2012;76(Suppl 1):S84-S91.

3. Sırmalı M, Türüt H, Kısacık E, Kaya S, Taştepe İ. Tracheobronchial foreign body aspirations in children. The Journal of Medical Investigations 2005;3(2):8-12.
4. Barlas ÜK. Çocuklarda yabancı cisim aspirasyonu. İçinde Barut A, Çiftci AÇ, Şahin AB (editörler). Pediatride Güncel Yaklaşımlar. 1. Baskı. İstanbul: Vadi Matbaacılık, 2020:211-219.

5. Campeli DN, Cotton EK, Lilly JR. A dual approach to tracheobronchial foreign bodies in children. Surgery 1982;91(2):178-182.

6. Hilliard T, Sim R, Saunders M, Hewer SL, Henderson J. Delayed diagnosis of foreignbody aspiration in children. Emerg Med J 2003;20(1):100-101.

7. Mallick MS. Tracheobronchial foreign body aspiration in children: a continuing diagnostic challenge. Afr J Paediatr Surg 2014;11(3):225-228.

8. Mortellaro VE, Iqbal C, Fu R, Curtis H, Fike FB, St Peter SD. Predictors of radiolucent foreign body aspiration. J Pediatr Surg 2013;48(9):1867-1870.

9. Yıldızeli B, Yüksel M. Trakeobronşiyal yabancı cisim as- pirasyonları. İçinde Yüksel M, Kalaycı G (editörler). Göğüs Cerrahisi. 1. Baskı. İstanbul: Özlem Grafik Matbaacılık; 2011;12(1):49-52.

10. Çelik P, Yorgancıoğlu A, Çelik O. Laringotrakeobronşial yabancı cisim aspirasyonu. KBB Klinikleri 2000;2:50-56.

11. Dikensoy O, Usalan C, Filiz A. Foreign body aspiration: clinical utility of flexible bronchoscopy. Postgrad Med J 2002;78(921):399403. 